\title{
$\beta$-glucuronidase and $\beta$-glucosidase Activity in Stool Specimens of Children with Inflammatory Bowel Disease
}

\author{
MARTA MROCZYŃSKA ${ }^{1}$, MIROSŁAWA GAŁĘCKA ${ }^{2}$, PATRYCJA SZACHTA ${ }^{2 *}$, DOROTA KAMODA ${ }^{1}$, \\ ZDZISŁAWA LIBUDZISZ ${ }^{1}$ and DOROTA ROSZAK ${ }^{3}$ \\ ${ }^{1}$ Institute of Fermentation Technology and Microbiology, Technical University of Łódź, Poland \\ ${ }^{2}$ Institute of Microecology in Poznań, Poland \\ ${ }^{3}$ First Department of Paediatrics, Department of Paediatric Gastroenterology and Metabolic Diseases, \\ Medical University in Poznań, Poznań
}

Submitted 6 August 2012, revised 20 May 2013, accepted 6 June 2013

\begin{abstract}
The aim of the study was to analyze the differences in the activity of $\beta$-glucuronidase and $\beta$-glucosidase in stool specimens of children with Inflammatory Bowel Diseases (IBD) and healthy subjects. The disease activity was determined according to the PCDAI scale (Crohn disease) and Truelove-Witts scale (Ulcerative colitis). Enzyme activity was determined by spectrophotometry. There was a correlation between the level of $\beta$ - glucosidase activity in stool and patient's age in the group of healthy controls, but not in the IBD group. $\beta$-glucosidase activity in IBD and healthy subjects stool specimens did not differ significantly. The activity of $\beta$-glucuronidase in children with IBD was two times lower than in the healthy group and was correlated with age in children with IBD, but not in the group of healthy ones.
\end{abstract}

Ke y w ord s: faecal enzymes, $\beta$-glucuronidase, $\beta$-glucosidase, inflammatory bowel disease

Inflammatory bowel disease (IBD) etiology remains unknown. Probably, three key factors are involved in disease development: genetic susceptibility, immune disorders and bacterial component (Ewaschuk et al., 2006). So far, an extensive search for the microbiological factor involved in IBD pathogenesis has not given the expected result. Chronic inflammation of the gastrointestinal tract may also be the result of inappropriate activation of the intestinal immune system (gut-associated lymphoid tissue - GALT) to autochtonic microbiota. Incorrect composition of microbiota, with a predominance of microorganisms with carcinogenic and/or mutagenic activity, is also considered as a possible cause of IBD development. In healthy individuals these microorganisms do not cause adverse health effects. When this potentially pathogenic bacterium becomes the dominant microflora, it could impair gastrointestinal tract functions, mainly due to enzymatic activity, which generates the synthesis of genotoxic, carcinogenic or mutagenic substances. Nowadays, we pay more attention to the role of two faecal enzymes, which can initiate the creation of unfavorable changes in the colon: $\beta$-glucuronidase and $\beta$-glucosidase. Many studies have shown a correlation between increased enzyme levels and increased production of damaging metabolites and intensified inflammation (Beaud et al., 2005; De Moreno de leBlanc and Perdigon, 2005; Hughes and Rowland, 2000).

$\beta$-glucuronidase is produced by cells of the liver, kidney, spleen, intestinal epithelium, endocrine and reproductive organs, but also by certain intestinal bacteria (Walaszek, 1990). The major producers of this enzyme are intestinal bacteria, especially Escherichia coli, Clostridium paraputrificum, Clostridium clostridioforme, Clostridium perfringens, Bacteroides fragilis, Bacteroides vulgatus, Bacteroides uniformis, Ruminococcus gnavus, Peptostreptococcus, Staphylococcus and Eubacterium (Arul et al., 2008; Akao, 2008). $\beta$-glucuronidase hydrolyses $\beta$-glucuronides to glucuronic acid and the aglycone i.e. imine, thiol or alcohol. $\beta$-glucuronidase elevated levels in plasma, is considered as a marker of increased risk of developing hormone-dependent cancers, particularly cancers of the breast and prostate. Increased enzyme activity was correlated with both malignancy and cancer type (Żołtaszek et al., 2008). For example, in patients with brain cancer, high concentrations of the enzyme were observed in the cerebrospinal

* Corresponding author: P. Szachta, Institute of Microecology, 10 Sielska, 60-129 Poznań, Poland; phone: +48 602441399; fax: +48 618626335; e-mail: pszachta@instytut-mikroekologii.pl 
fluid (Walaszek, 1993). The increased concentration of enzyme of microbial origin is characteristic for colorectal cancer (De Moreno de leBlanc and Perdigon, 2005). Increased levels of $\beta$-glucuronidase in stool seem to be physiological for men, especially aged 25 to 60 years. What is interesting, elevated enzyme level doesn't occur in healthy non-pregnant women (Kim and Jin, 2001). The activity of this enzyme is stimulated by contact with toxic substances, tobacco smoke or carcinogens. On the other hand, low-calorie and vegetarian diet is a useful tool to reduce the level of $\beta$-glucuronidase in the stool (Reddy et al., 1974; Mykkänen et al.,1997). A diet rich in red meat and protein increases the amount of the enzyme, because of stimulating microbial producers growth. It should be emphasized, that antibiotic treatment leads to increased level of the enzyme in the colon (Źółtaszek et al., 2008). This observation indicates the important role microbiota play in regulating $\beta$-glucuronidase levels in the colon.

$\beta$-glucosidase, the second analyzed enzyme is produced the most intensively by Bacteroides uniformis, Clostridium paraputrificum, clostridioformes Clostridium, Enterococcus faecalis. There are no studies evaluating $\beta$-glucosidase activity in health and disease. The enzyme's main role is hydrolysis of glycosides to aglycones and sugar components. Glycosides aren't hydrolyzed in the higher part of gastrointestinal tract part, but are hydrolyzed in the colon by bacterial $\beta$-glycosidases. As a result, potentially toxic substances (f.ex. quercetin), may be formed in the large intestine. It is thought that production of harmful substances could be higher among people eating a lot of vegetables, cause of their richness in glycosides. The activity of $\beta$-glucuronidase and $\beta$-glucosidase in stool specimens of children with IBD has not yet been studied. Because of procarcinogenic and proinflammatory activity of enzymes and the fact that the activity of the enzymes is higher in stool specimens of patients with cancer, we attempt to assess enzyme activity in the stool of children with organic gastrointestinal disease.

68 children with IBD hospitalised in the Department of Paediatric Gastroenterology and Metabolic Diseases participated in the study. The activity of the disease was evaluated for each patient. Diagnosis of the disease was made according to the generally accepted scheme of diagnostic proceeding, including: medical history (anamnesis), physical (subjective) examination, and laboratory tests, endoscopic examination, radiological imaging and histopathological examination. In CD patients, the Pediatric Crohn's Disease Activity Index (PCDAI) was determined (0-10 points - no activity; 11-25 points - mild state; $26-50$ points - moderate state; $>51$ points - severe state). In CU patients activity of the disease was evaluated using Truelove-Witts index (0-5 points - mild state; $5-8$ points - moderate state;
9-12 points - severe state). CI is regarded as a indeterminate colitis, which can proceed on full-blown IBD. The state of disease activity wasn't assessed in CI manifestation. The control group consisted of 38 healthy children. The study obtained approval from the Ethical Committee at the "Karol Marcinkowski" Medical University in Poznań.

A sample of stool was collected from each child to evaluate $\beta$-glucuronidase and $\beta$-glucosidase activity. Prior to collecting faeces samples an informed consent for participation in the analysis was obtained (from patient or his/her guardian, for children under the age of 16 years). For determination of enzyme activity, stool specimens were suspended in phosphate buffer, subjected to homogenization, and sonication with appropriately selected parameters of the device. The enzymatic activity of $\beta$-glucuronidase ( $\beta$-glucosidase) was determined by spectrophotometry, specifying the amount of phenolphthalein ( $\mathrm{p}$-nitrofenol) released during the hydrolysis of $10 \mathrm{mM}$ phenolphthalein$\beta$-D-glucopyranoside (20 mM p-nitrophenol- $\beta$-Dglucosidase). The samples were centrifuged after sonication. Then the collected supernatant (containing the enzyme) was transferred to test tubes and $1 \mathrm{ml}$ of $0.02 \mathrm{M}$ phosphate buffer $\mathrm{pH}=7$, and $0.1 \mathrm{ml}$ of phenolphthalein- $\beta$-D-glucopyranoside ( $p$-nitrophenol$\beta$-D-glucopyranoside) was added to it. The samples prepared in such a way were incubated in a water bath for $15 \mathrm{~min}$ at $37^{\circ} \mathrm{C}$ (for $60 \mathrm{~min}$ at $37^{\circ} \mathrm{C}$ ), after that the reaction was stopped by adding glycine buffer (sodium hydroxide). The contents of the tubes were mixed thoroughly and the absorbance level was measured at wavelength $\lambda=540 \mathrm{~nm},(\lambda=450 \mathrm{~nm})$ with regard to similarly prepared and heated control sample, which contained water instead of the substrate.

A unit of activity was adopted as such amount of phenolphthalein (for $\beta$-glucuronidase) and p-nitrophenol (for $\beta$-glucosidase) expressed in $\mathrm{mM}$ released during the reaction throughout $1 \mathrm{~h}$ per $1 \mathrm{mg}$ of protein. The total concentration of protein in bacterial cells was determined by the Lowry method.

All statistical analyses were performed using Statistica 7.0. The activity of $\beta$-glucuronidase and $\beta$-glucosidase in stool samples was compared between study and control groups. Differences in the levels of enzymes, depending on the age of the children were also analyzed. Correlations between $\beta$-glucuronidase and $\beta$-glucosidase activity and clinical disease manifestation (CU, CD, CI), activity state and phase of treatment were evaluated. To determine the reason for different enzyme activities between the study and control group, the disparity in number of bacteria producing $\beta$-glucuronidase and $\beta$-glucosidase was checked. Statistical significance for the confidence interval 0.05 was determined using One-Way ANOVA test. 
The characteristics of study and control group, in view of average age and number of children in each group, is presented in table I. The study group was divided into three subgroups, according to disease clinical manifestation (CD, CU, CI) disease activity state. The range of $\beta$-glucuronidase activity in stool specimens of children with IBD and healthy ones is presented in table II and for $\beta$-glucosidase in table III.

$\beta$-glucuronidase activity was statistically significantly different in stool samples of children with IBD and healthy children. Enzyme mean value in children with IBD stool specimens was twice lower than in the control group, but wasn't statistically different in different IBD clinical manifestations (CD, CU, CI). It is worth noting that the enzyme activity was highly differentiated in stool specimens of children with CI. $\beta$-glucuronidase activity in the study group and didn't depend on age, but in control group did. In stool specimens of healthy children enzyme activity correlated with age. The results are presented in figure $1(\mathrm{~A}, \mathrm{~B}, \mathrm{C}, \mathrm{D})$.

There were no statistically significant differences in $\beta$-glucosidase activity in stool specimens of chil- dren with IBD and healthy ones. In stool specimens of children with CI enzyme activity was highly differentiated and also higher than in the stool of healthy children. $\beta$-glucosidase activity in stool samples wasn't statistically significantly different in CU and CD. $\beta$-glucuronidase activity in control group didn't depend on age, but in IBD group correlated with age. These correlations are presented in figure 2.

$\beta$-glucuronidase and $\beta$-glucosidase activity range in IBD clinical manifestations $(\mathrm{CU}, \mathrm{CD}, \mathrm{CI})$ is presented in table IV. Data are presented before and after treatment.

We found no statistically significant differences in enzyme activity in stool specimens before and after treatment, regardless of type of treatment (antibiotics, steroids or antibiotics and steroids together)

This is the first study evaluating $\beta$-glucuronidase and $\beta$-glucosidase activity in stool specimens of children with IBD. The control group consisted of healthy children, without any organic changes in the gastrointestinal tract. $\beta$-glucuronidase has a rather negative effect on human health. The enzyme disrupts glucuronidation, which is very important element of the

Table I

Study and control group characteristic

\begin{tabular}{|c|c|c|c|c|c|c|c|c|c|}
\hline & $\begin{array}{l}\text { Control } \\
\text { group }\end{array}$ & \multicolumn{4}{|c|}{$\mathrm{CD}$} & \multicolumn{3}{|c|}{$\mathrm{CU}$} & CI \\
\hline Total patient's number & 38 & \multicolumn{4}{|c|}{25} & \multicolumn{3}{|c|}{26} & 17 \\
\hline Disease activity state & - & $\begin{array}{c}\text { No } \\
\text { activity }\end{array}$ & $\begin{array}{l}\text { Mild } \\
\text { state }\end{array}$ & $\begin{array}{l}\text { Moderate } \\
\text { state }\end{array}$ & $\begin{array}{l}\text { Severe } \\
\text { state }\end{array}$ & $\begin{array}{l}\text { Mild } \\
\text { state }\end{array}$ & $\begin{array}{l}\text { Moderate } \\
\text { state }\end{array}$ & $\begin{array}{l}\text { Severe } \\
\text { state }\end{array}$ & - \\
\hline Patients number in group & - & 10 & 2 & 8 & 3 & 18 & 4 & 4 & - \\
\hline Age & $1-18$ & \multicolumn{4}{|c|}{$6-18$} & \multicolumn{3}{|c|}{$1.5-18$} & $3-17.5$ \\
\hline Mean age & 6.63 & \multicolumn{4}{|c|}{14.1} & \multicolumn{3}{|c|}{13.8} & 11.6 \\
\hline
\end{tabular}

Table II

$\beta$-glucuronidase activity in stool of children from study and control group

\begin{tabular}{|c|c|c|c|}
\hline \multicolumn{4}{|c|}{$\beta$-glucuronidase activity $\left[(\mathrm{mM} / \mathrm{mg})^{*} \mathrm{~h}\right]$} \\
\hline \multicolumn{3}{|c|}{ Study group } & Control group \\
\hline \multicolumn{3}{|c|}{$0.12-81.63$} & \multirow{3}{*}{$\begin{array}{c}5.82-141.13 \\
\text { (mean value } 44.86)\end{array}$} \\
\hline $\mathrm{CU}$ & CD & IC & \\
\hline $\begin{array}{c}0.12-57.93 \\
\text { (mean value } 11.48 \text { ) }\end{array}$ & $\begin{array}{c}0.39-37.62 \\
\text { (mean value } 12.5 \text { ) }\end{array}$ & $\begin{array}{c}2.42-81.63 \\
\text { (mean value } 23.61 \text { ) }\end{array}$ & \\
\hline
\end{tabular}

Table III

$\beta$-glucosidase activity in stool of children from study and control group

\begin{tabular}{|c|c|c|c|}
\hline \multicolumn{3}{|c|}{$\beta$-glukosidase activity $\left[(\mathrm{mM} / \mathrm{mg})^{*} \mathrm{~h}\right]$} & \multirow{2}{*}{$\begin{array}{c}\text { Control group } \\
\text { Study group } \\
0.18-1.08 \\
\text { (mean value 0.54) }\end{array}$} \\
\hline CU & CD & IC & \\
\hline $\begin{array}{c}0.03-2.2 \\
\text { (mean value } 0.41)\end{array}$ & $\begin{array}{c}0.031-0.879 \\
\text { (mean value } 0.31)\end{array}$ & $\begin{array}{c}0.13-1.78 \\
\text { (mean value } 0.59)\end{array}$ & \\
\hline
\end{tabular}


Table IV

$\beta$-galactosidase and $\beta$-glucosidase activity in children with IBD, before and after treatment

\begin{tabular}{|c|c|c|c|}
\hline \multicolumn{2}{|c|}{ CD } & \multicolumn{2}{c|}{ CU } \\
\hline $\begin{array}{c}\beta \text {-glucuronidase activity before } \\
\text { treatment }\left[(\mathrm{mM} / \mathrm{mg})^{\star} \mathrm{h}\right]\end{array}$ & $\begin{array}{c}\beta \text {-glucuronidase activity after } \\
\text { treatment }\left[(\mathrm{mM} / \mathrm{mg})^{\star} \mathrm{h}\right]\end{array}$ & $\begin{array}{c}\beta \text {-glucosidase activity before } \\
\text { treatment }\left[(\mathrm{mM} / \mathrm{mg})^{\star} \mathrm{h}\right]\end{array}$ & $\begin{array}{c}\beta \text {-glucosidase activity after } \\
\text { treatment }\left[(\mathrm{mM} / \mathrm{mg})^{\star} \mathrm{h}\right]\end{array}$ \\
\hline $2.03-37.62$ & $0.39-29.81$ & $1.72-81.63$ & $0.11-57.93$ \\
\hline $\begin{array}{c}\beta \text {-glucosidase activity before } \\
\text { treatment }\left[(\mathrm{mM} / \mathrm{mg})^{\star} \mathrm{h}\right]\end{array}$ & $\begin{array}{c}\beta \text {-glucosidase activity after } \\
\text { treatment }\left[(\mathrm{mM} / \mathrm{mg})^{\star} \mathrm{h}\right]\end{array}$ & $\begin{array}{c}\beta \text {-glucosidase activity before } \\
\text { treatment }\left[(\mathrm{mM} / \mathrm{mg})^{\star} \mathrm{h}\right]\end{array}$ & $\begin{array}{c}\beta \text {-glucosidase activity after } \\
\text { treatment }\left[(\mathrm{mM} / \mathrm{mg})^{\star} \mathrm{h}\right]\end{array}$ \\
\hline $0.019-0.88$ & $0.042-0.49$ & $0.081-1.78$ & $0.02-2.19$ \\
\hline
\end{tabular}

detoxification process in humans. During glucuronidation xenobiotics and active metabolites are conjugated, which makes them easier to be expelled from the body. Consequently, the reduction of an aglikon's negative influence is achieved through glucuronidation (Kaivosaari et al., 2011). $\beta$-glucuronidase catalyzes the process of deconjugation, which is the reverse of glucuronidation. In this way, the described enzyme increases the time of acting and potentially harmful impact on human organism exerted by substances like hormones, drugs or carcinogens (Hanausek et al., 2003; Walaszek, 1993). $\beta$-glucuronidase activity is significantly elevated in oncological patients, especially in tissue directly affected by carcinogenesis process. Studies have shown that $\beta$-glucuronidase activity increases in patients with central nervous system tumors, colorectal, bladder and breast cancer (Walaszek et al., 1986; Walaszek, 1990; Kim and Jin, 2002). This is the reason why activities aimed at reduction of the enzyme's level, are one of the main research directions for the mentioned dis-
A)

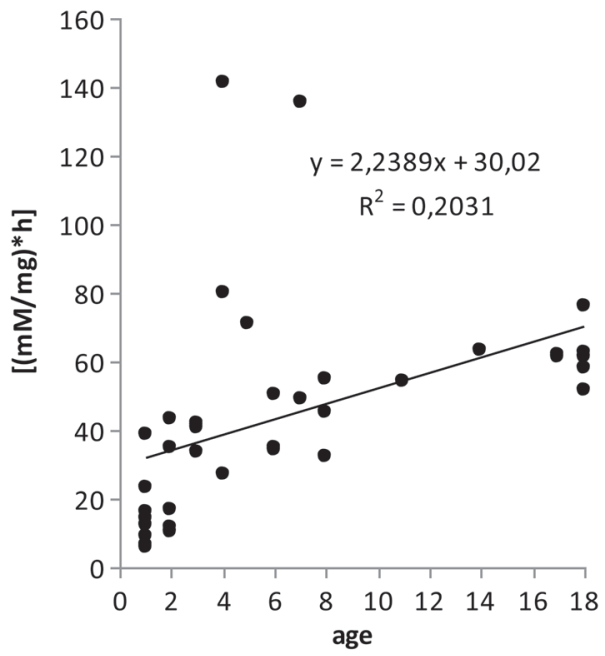

C)

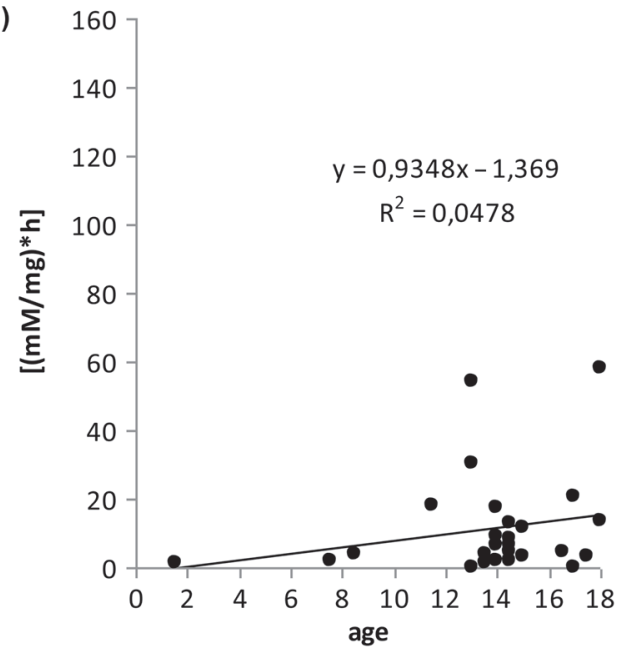

B)

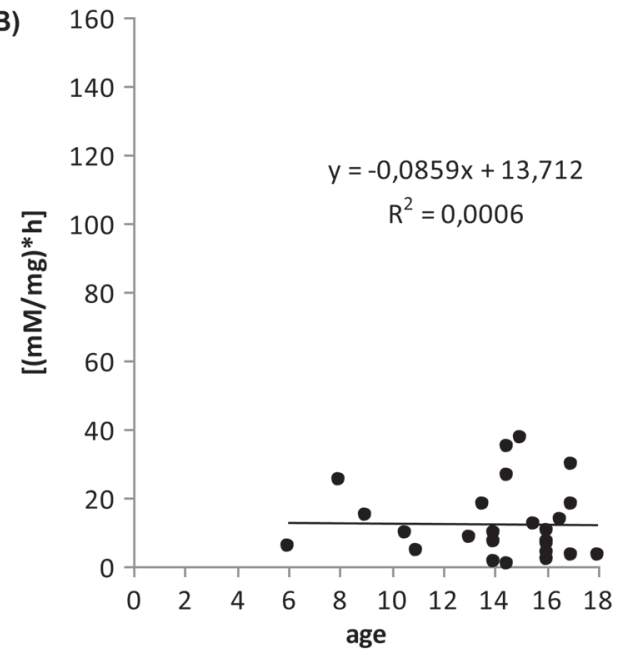

D)

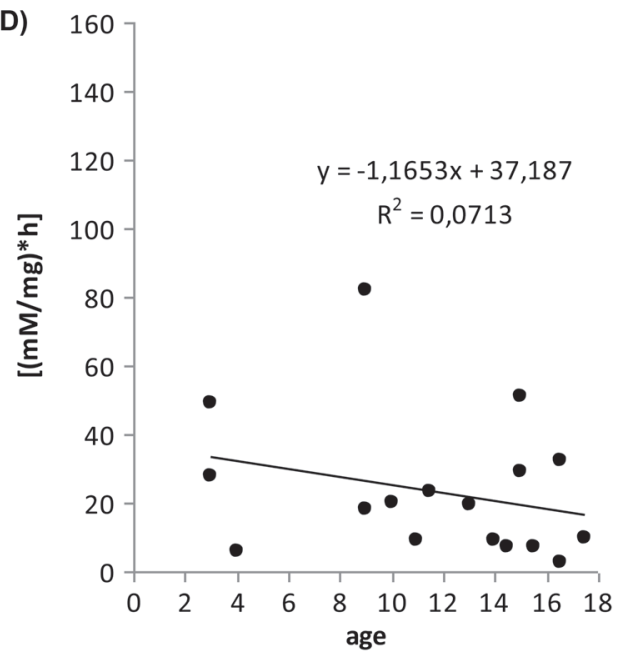

Fig. 1. $\beta$-glucuronidase activity in control group (a), children with CD (b), children with CU (c), children with CI (d) 

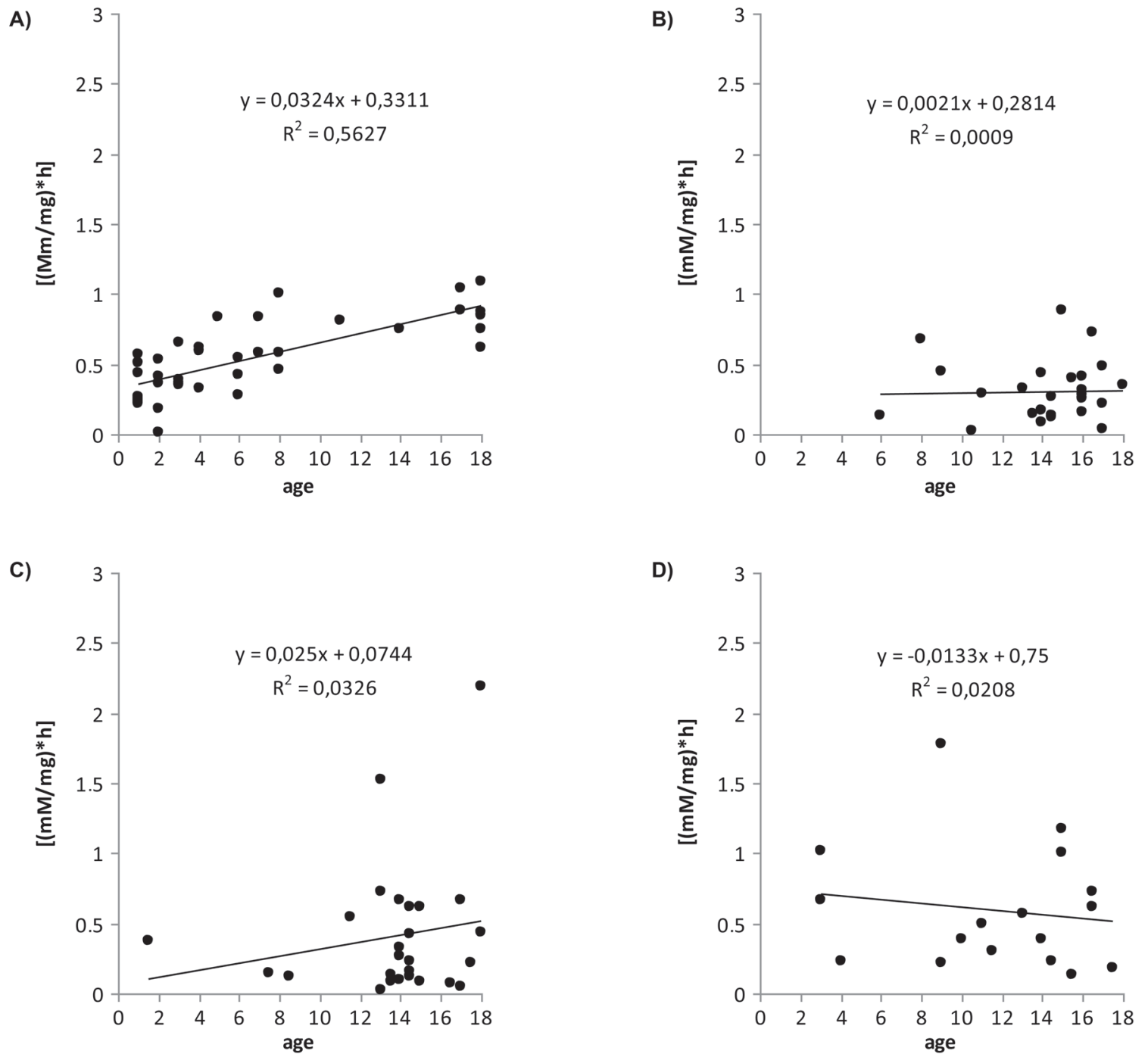

Fig. 2. $\beta$-glucosidase activity in control group (a), children with CD (b), children with CU (c), children with CI (d)

ease. A study evaluating $\beta$-glucuronidase activity in stool specimens of children with IBD, showed surprisingly low levels of enzyme in study group. The enzyme activity in stool specimens of children with IBD was 2.5 times lower than in healthy individuals. At this point, it should be reminded, that in IBD disrupted activation of the immune response, chronic inflammation and changed microbiota composition was demonstrated. Reducing the activity of $\beta$-glucuronidase in IBD group may also indicate a loss of physiological properties of intestinal secretory cells. It is also possible, that $\beta$-glucuronidase activity reduction is one of the mechanisms of disease development. Explanations also called for a very diverse level of enzyme activity in children with CI (2.42 to 81.63). It seems like the observed values of $\beta$-glucuronidase activity, are on the borderline characteristic of healthy children (5.82 to $141.13)$ to the value characteristic of children with IBD (93\% of the samples came from the range 0.12-37.62). Histopathological examination interpreted colitis inde- terminata as a transition state, before the development of full - blown IBD. Diverse $\beta$-glucuronidase activity in CI group, may reflect a patient's current status. In this aspect, the characterized enzyme has a chance to become a valuable IBD risk indicator. $\beta$-glucuronidase activity isn't significantly different depending on the disease manifestation (CU, CD). It can indicate that the causal factor in $\mathrm{CU}$ and $\mathrm{CD}$ development is common.

Reduction of $\beta$-glucuronidase activity in stool specimets of children with IBD can also result from loss of secretory cells function, probably because of chronic inflammation or/and used drugs. In children with CI, the period of illness is shorter and the degree of damage to the gastrointestinal tract is lower. Probably because of this, the activity of the fecal enzyme is higher in CI compared with CD and CU.

In some percent of CI patients, the development of $\mathrm{CD}$ or $\mathrm{CU}$ is observed, while in the remainder of them the disease remains permanently classified as $\mathrm{CI}$ or going to recuperation (Tremaine, 2012). The authors 
assume that the diverse range of enzyme activity in children with CI stool specimens, may reflect the direction of the future course of the disease. Further investigation of $\beta$-glucuronidase activity in stool samples of children with $\mathrm{CI}$ are necessary.

What is interesting, $\beta$-glucuronidase activity in stool specimens is correlated with children's age in the control group, but in IBD group is not. The increase in the enzyme activity in stool specimens of older children seems to be a physiological process, correlated with diet modification and - consequently - change of microbiota composition (Enck et al., 2009). The effect of diet on $\beta$-glucuronidase activity has already been reported in the literature (De Preter et al., 2008; Nakamura et al., 2002; Haberer et al., 2003).

To a monotonous child's diet, new ingredientsespecially meat and dairy products - are gradually introduced. New diet stimulating the multiplication of $\beta$-glucuronidase producing bacteria, like Escherichia coli, Clostridium spp., Bacteroides spp. and Eubacterium spp., leads to increased $\beta$-glucuronidase activity in stool specimens. What is important, we can't exclude the possibility, that not only the amount, but the host bacterial production capacity, has a significant impact on the overall activity of $\beta$-glucuronidase in faeces. Mroczyńska et al. reported that different strains of the same bacterial species, have different ability to secrete of $\beta$-glucuronidase and $\beta$-glucosidase, depending on a patient's age (Mroczyńska and Libudzisz, 2010). Intestinal bacteria of children with IBD may have a reduced capacity to secrete some enzymes (including $\beta$-glucuronidase), compared to a healthy individual's intestinal bacteria. Finally, we can't exclude that $\beta$-glucuronidase activity reduction in stool specimens results from reducing the number of bacteria, which we can't detect with the available research methods. In a way, this undiscovered yet bacterial agent, which could be the direct cause of IBD, is being looked for by a lot of scientific teams (Takaishi et al., 2008).

Analysis of $\beta$-glucosidase activity in stool specimens showed no significant differences between the study and control groups. Enzymes activity correlated with age in the IBD group, but not in the control group. Mroczynska et al., showed that $\beta$-glucosidase activity isolated from selected bacteria strains was 32\% higher in healthy children than in healthy adults (Mroczyńska and Libudzisz, 2010). It seems that in the state of health, levels of the enzyme (at least of bacterial origin) do not correlate with age, on the contrary - they decrease. Meanwhile, in children with IBD, we observe an inverse relationship - the level of $\beta$-glucosidase correlates with age. No statistically significant differences in the activity of $\beta$-glucosidase between the study and control groups can result from a relatively short period of illness in the paediatric population. Because of the carcinogenic proper- ties of $\beta$-glucosidase we find it necessary to determine the enzyme level in the stool specimens of older patients with IBD, in whom the duration of the disease and thus treatment, is much longer than in the paediatric group.

Confirmation, that enzyme activity is significantly higher in adult patients with IBD (what is suggested by a positive correlation between enzyme levels and age) may result in the development of alternative and noninvasive methods of treatment in IBD patients. This goal may be achieved by modification of the diet by means of fruit and vegetables reduction. Such dietary behavior leads to decreased activity of $\beta$-glucosidase in stool specimens. However, the lack of significant differences in $\beta$-glucosidase activity in IBD and healthy children stool suggests that this enzyme appears to be a less valuable indicator of IBD, than $\beta$-glucuronidase.

The actual significance of both the enzymes in the pathogenesis and/or maintaining IBD should be the subject of further research. The presented analysis is the first one describing the activity of $\beta$-glucuronidase and $\beta$-glucosidase in the stool specimens of children with IBD, in comparison to healthy ones. Differences in enzymatic activity between sick and healthy children are evident, particularly in relation to $\beta$-glucuronidase activity. The authors believe that further analysis of this particular enzyme may contribute to recognizing the real cause and mechanism of sustained IBD.

All of the authors have no conflict of interest to declare. All of the authors have no funding sources to declare.

\section{Literature}

Akao T. 1999. Purification and characterization of glycyrrhetic acid mono-glucuronide $\beta$-D-glucuronidase in Eubacterium sp. GLH. Biol. Pharm. Bull. 1: 80-82

Arul L., G. Benita and P. Balasubramanian. 2008. Functional insight for $\beta$-glucuronidase in Escherichia coli and Staphylococcus sp. RLH1. Bioinformation 2: 339-343

Beaud D., P. Tailliez and J. Anba-M Ondoloni. 2005. Genetic characterization of the $\beta$-glucuronidase enzyme from a human intestinal bacterium, Ruminococcus gnavus. Microbiology 151: 2323-2330.

De Moreno de leBlanc A. and G. Perdigon. 2005. Reduction of $\beta$-glucuronidase and nitroreductase activity by yoghurt in a murine colon cancer model. Biocell 29: 15-24.

De Preter, H. Raemen, L. Cloetens, E. Houben and K. Verbeke. 2008. Effect of dietary intervention with different pre-and probiotics on intestinal bacterial enzyme activities. Eur. J. Clin. Nutr. 62: 225-231.

Enck P., K. Zimmermann, K. Rusch, A. Schwiertz, S. Klosterhalfen and J.S. Frick. 2009. The effects of maturation on the colonic microflora in infancy and childhood. Gastroenterol Res Pract. 752401 Ewaschuk J.B. and L.A. Dieleman. 2006. Probiotics and prebiotics in chronic inflammatory bowel diseases. World J. Gastroenterol. 7: 5941-5950

Haberer P., M. du Toit, L.M.T. Dicks, F. Ahvens and W.H. Halzapfel. 2003. Effect of potentially probiotic lactobacilli on faecal enzyme activity in minipigs on a high-fat, high-cholesterol diet-a preliminary in vivo trial. Int. J. Food. Microbiol. 87: 287-291. 
Hanausek M., Z. Walaszek and T.J. Slaga. 2003. Detoxifying cancer causing agents to prevent cancer. Integr. Cancer Ther. 2: 139-144 Hughes R. and I.R. Rowland. 2000. Metabolic activities of the gut microflora in relation to cancer. Microb. Ecol. Health Dis. 12: $179-185$.

Kaivosaari S., M. Finel and M. Koskinen. 2011. N-glucuronidation of drugs and other xenobiotics by hum an and animal UDP-glucuronosyltransferases. Xenobiotica 41: 652-669.

Kim DH and Y.H. Jin. 2001. Intestinal bacterial beta-glucuronidase activity of patients with colon cancer. Arch. Pharm. Res. 24: 564-567 Mroczynska M. and Z. Libudzisz. 2010. $\beta$-glucuronidase and $\beta$-glucosidase activity of lactobacillus and enterococcus isolated from human feces. Pol. J. Microbiol. 59: 265-269.

Mykkänen H., J. Tikka, T. Pitkänen and O. Hänninen. 1997. Fecal bacterial enzyme activities in infants increase with age and adoption of adult-type diet. J. Pediatr. Gastroenterol. Nutr. 25: 312-316.

Nakamura J., Y. Kubota, M. Miyaoka, T. Saitch, F. Mizuno and Y. Benno. 2002. Comparison of four microbial enzymes in Clostridia and Bacteroides isolated from human feces. Microbiol. Immunol. 46: 487-490

Pegram R.A., W.T. Allaben and M.W. Chou. 1989. Effect of caloric restriction on afl atoxin B1-DNA adduct formation and associated factors in Fischer 344 rats: preliminary findings. Mech. Ageing. Dev. 48: 167-177.

Reddy B.S., J.H. Weisburger and E.L. Wynder. 1974. Fecal bacterial b-glucuronidase: control by diet. Science 183: 416-417.

Takaishi H., T. Matsuki, A. Nakazawa, T. Takada, S. Kado, T. Asahara, N. Kamada, A. Sakuraba, T. Yajima, H. Higuchi, N. Inoue, H. Ogata, Y. Iwao, K. Nomoto, R. Tanaka and T. Hibi. 2008. Imbalance in intestinal microflora constitution could be involved in the pathogenesis of inflammatory bowel disease. Int. J. Med. Microbiol. 298: 463-472.

Tremaine WJ. 2012. Is Indeterminate Colitis Determinable? Curr. Gastroenterol. Rep. 14: 162-165.

Walaszek Z., M. Hanausek-Walaszek and T.E. Webb. 1986. Dietary glucarate-mediated reduction of sensitivity of murine strains to chemical carcinogenesis. Cancer Lett. 33: 25-32.

Walaszek Z. 1993. Chemopreventive properties of D-glucaric acid derivatives. Cancer Bull. 45: 453-457.

Walaszek Z. 1990. Potential use of D-glucaric acid derivatives in cancer prevention. Cancer Lett. 54: 1-8

Żołtaszek R., M. Hanausek, Z.M. Kiliańska and Z. Walaszek. 2008. The biological role of D-glucaric acid and its derivatives: Potential use in medicine. Postępy Hig. Med. Dośw. 62: 451-462. 